\title{
AMNIOTIC FLUID INSULIN-LIIKE GROWTH FACTOR BINDING- PROTEIN 3 CONCENTRATION AS EARLY INDICATOR OF FETAL GROWTH RESTRICTION
}

\author{
THESE \\ préparée sous la direction du Docteur Stefan Gerber, \\ Privat-Docent et Maître d'Enseignement et de Recherche \\ et présentée à la Faculté de biologie et de médecine de \\ l'Université de Lausanne pour l'obtention du grade de
}

DOCTEUR EN MEDECINE

par

WQ

210.5

Géraldine MURISIER - PETETIN

BMTE 3527

Mur

Médecin diplômée de la Confédération Suisse

Originaire de St-Légier (VD)

Lausanne

2009 
et de mederine

\section{Imprimatur}

Vu le rapport présenté par le jury d'examen, composé de

Directeur de thèse Monsieur le Docteur Stefan Gerber

Co-Directeur de thèse

Expert

Monsieur le Professeur associé François Pralong

Directrice de l'Ecole Madame le Professeur Stephanie Clarke doctorale

la Commission MD de l'Ecole doctorale autorise l'impression de la thèse de Madame Géralldine Murisier-Petetin

intitulée

Ammiotic fluid insulin-like growth factor binding protein 3 concentration as early indicator of fetal growth restriction

Lausanne, le 7 juillet 2009

pour Le Doyen

de la Faculté de Biologie et de Médecine

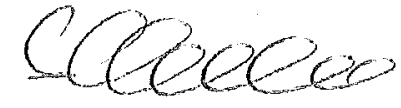

Madame le Professeur Stephanie Clarke Directrice de l'Ecole doctorale 


\section{Rapport de synthèse}

\section{La concentration d'IGFBP-3 dans le liquide amniotique, un indicateur précoce de la croissance intra-utérine}

\section{Introduction :}

La croissance foetale intra-utérine dépend d'un grand nombre de facteurs maternels, placentaires et fœtaux. Une inadéquation d'un ou plusieurs de ces facteurs peut induire un retard de croissance intra-utérin (RCIU) ou au contraire une macrosomie. Les principales causes de RCIU comprennent les infections maternelles, l'éclampsie, les cardiovasculopathies maternelles, la toxicomanie, les malformations fœetales et les insuffisances placentaires. Les facteurs endocriniens constituent un petit pourcentage des causes de RCIU, mais méritent que l'on s'y intéresse de plus près. Les facteurs hormonaux les plus importants pour la croissance fœtale sont l'insuline et les insuline-like growth factors (IGFs) et non l'hormone de croissance $(\mathrm{GH})$ qui joue un rôle majeur dans la croissance postnatale.

Notre attention s'est portée sur IGF-1 qui joue un rôle important dans la croissance intrautérine. Sa biodisponibilité dépend de plusieurs protéines plasmatiques, les IGF-binding proteins (IGFBP 1 à 9). IGFBP-3 est la principale de ces IGFBPs, autant d'un point de vue quantitatif que fonctionnel.

Nous avons cherché à déterminer si les concentrations d'IGF-1 et d'IGFBP-3 dans le liquide amniotique au début du deuxième trimestre étaient prédictives de la croissance intra-utérine.

Les gènes codant pour IGF-1 et IGFBP-3 contenant certaines séquences polymorphiques, nous avons également étudié leur influence sur la croissance foetale.

L'analyse du liquide amniotique présente l'avantage de pouvoir être effectuée dès la $14^{\text {ème }}$ semaine d'aménorrhée alors que la biométrie foetale échographique ne permet pas à ce stade de déceler des anomalies de la croissance intra-utérine.

\section{Méthode :}

Nous avons analysé des échantillons de liquide amniotique prélevés entre la $14^{\text {ème }}$ et la $18^{\text {ème }}$ semaine de grossesse chez 196 patientes. Les concentrations d'IGF-1 et d'IGFBP-3 ont été dosées par ELISA, les polymorphismes analysés par PCR. Ces résultats ont été ensuite analysés en fonction du poids de naissance des nouveaux-nés, répartis en trois groupes: normal pour l'âge gestationnel (AGA), petit pour l'âge gestationnel (SGA) et grand pour l'âge gestationnel (LGA).

\section{Résultats :}

Les concentrations d'IGFBP3 dans le liquide amniotique sont significativement plus élevées $(p=0.030)$ dans le groupe SGA par rapport au groupe AGA, d'autant plus quand les taux sont ajustés en fonction de paramètres tels que l'âge gestationnel lors de l'amniocentèse (ANCOVA analysis : $p=0.009$ ). La distribution du polymorphisme VNTR (variable number of tandem repeat) dans la région promotrice d'IGF-1 au sein du groupe SGA est significativement différente de celle du groupe AGA ( $p=0.029)$. En effet, la fréquence de l'association allélique 19CA/20CA est diminuée dans le groupe SGA.

Nous n'avons pas identifié de différence de distribution des séquences polymorphiques d'IGFBP-3 entre les différents groupes.

\section{Conclusion :}

Une concentration élevée d'IGFBP-3 dans le liquide amniotique au début du deuxième trimestre est associée à un risque plus élevé de retard de croissance alors que l'association allélique $19 \mathrm{CA} / 20 \mathrm{CA}$ dans la région polymorphique $I G F-I$ VNTR est un facteur protecteur. 


\title{
European Journal of Obstetrics \& Gynecology and Reproductive Biology
}

journal homepage: www.elsevier.com/locatelejogrb

\section{Amniotic fluid insulin-like growth factor binding protein 3 concentration as early indicator of fetal growth restriction}

\author{
Geraldine Murisier-Petetin, Sandrine Gremlich, Francoise Damnon, Danielle Reymondin, \\ Patrick Hohlfeld, Stefan Gerber* \\ Department of Gynecology, Obstetrics and Medical Genetics, CHUV Hospital, Av. Pierre-Decker 2, 1011 Lausanne, Switzerland
}

A RTICLE INFO

\section{Article history:}

Received 31 July 2007

Received in revised form 23 September 2008 Accepted 13 January 2009

\section{Keywords:}

Insulin-like growth factor

Fetal growth

Polymorphism

Amniotic fluid

\begin{abstract}
A B S T R A T
Objective: Insulin-like growth factor-I (IGF-I) is an important regulator of fetal growth and its bioavailability depends on insulin-like growth factor binding proteins (IGFBPs). Genes coding for IGF-I and IGFBP3 are polymorphic. We hypothesized that either amniotic fluid protein concentration at the beginning of the second trimester or genotype of one of these two genes could be predictive of abnormal fetal growth.

Study design: Amniotic fluid samples (14-18 weeks of pregnancy) from 123 patients with appropriate for gestational age (AGA) fetuses, 39 patients with small for gestational age (SGA) fetuses and 34 patients with large for gestational age (LGA) were analyzed. Protein concentrations were evaluated by ELISA and gene polymorphisms by PCR.

Results: Amniotic fluid lGFBP3 concentrations were significantly higher in SGA compared to AGA group $(P=0.030)$, and this was even more significant when adjusted to gestational age at the time of amniocentesis and other covariates (ANCOVA analysis: $P=0.009$ ). Genotypic distribution of IGF-I variable number of tandem repeats (VNTR) polymorphism was significantly different in SGA compared to AGA group $(P=0.029)$. 19CA/20CA genotype frequency was threefold decreased in SGA compared to AGA group and the risk of SGA occurrence of this genotype was decreased accordingly: $O R=0.289$, $95 \% \mathrm{CI}=0.1-0.9, P=0.032$. Genotype distribution of IGFBP3(A-202C) polymorphism was similar in all three groups.

Conclusions: High IGFBP3 concentrations in amniotic fluid at the beginning of the second trimester are associated with increased risks of SGA while 19CA/20CA genotype at IGF-I VNTR polymorphism is associated with reduced risks of SGA. Neither IGFBP3 concentrations, nor IGF-1/IGFBP3 polymorphisms are associated with modified risks of LGA.
\end{abstract}

(C) 2009 Elsevier Ireland L.td. All rights reserved.

\section{Introduction}

Intrauterine growth is a complex process depending on maternal, fetal and placental factorș, but also on environmental conditions. It is principally controlled by growth hormoneindependent insulin-like growth factor (IGF) production until just before birth [1-4].

There are two forms of IGF, IGF-I and -II, in which none is able to cross the placental barrier. Animal experiments have shown that IGF-I was principally involved in fetal and postnatal growth/ development and IGF-II in placental development [5-8]. 75-80\% of IGF is present as a complex with ALS (acid-labile subunit) and insulin-like growth factor-binding protein 3 (IGFBP3), 20-25\% is associated with other IGFBPs, and less than $1 \%$ is free [9]. IGFBPs

\footnotetext{
* Corresponding author. Tel:: +412131433 60; fax: +41213143525.

E-mail address: Stefan.Gerber@chuv.hospvd.ch (S. Gerber).
}

increase IGF half-life, control IGF transport, regulate IGF-IGF receptor interaction and also prevent cell growth overstimulation [5]. But IGFBPs also act through their own receptors, inducing pathways sometimes opposed to IGF actions such as cellular growth inhibition or apoptosis stimulation $[2,5]$.

Previous studies in mice have shown that IGF-I KO resulted in intrauterine growth retardation and post-weaning growth defect $[10,11]$, and ALS KO in a modest reduction in postnatal growth [12].

No clear association between birth weight and IGF family members levels in amniotic fluid (AF) at the beginning of the second trimester could be demonstrated $[4,13,14]$, although Tisi et al. reported a significant association between AF IGFBP3 level and newborn birth weight in macrosomes [15].

Genes coding for IGF-I and IGFBP3 are polymorphic. IGF-I gene was shown to contain a Variable Number of Tandem Repeats (VNTR) in the promoter region and IGFBP3 gene a single nucleotide polymorphism $(\mathrm{SNP})(\mathrm{A} \rightarrow \mathrm{C})$ at position -202 in the promoter region. 
If some controversy exists on the association between IGF-I VNTR and IGF-I serum values, most studies showed a significant reduction of IGF-I concentrations in non-carriers of the most common allele, 19CA [16-20]. IGFBP3 SNP was shown to correlate with adult IGFBP3 serum concentrations, the mutated $C$ allele being associated with decreased circulating concentrations $[21,22]$.

Most of the studies looking at the fetal somatotropic axis used cord blood at delivery as starting material. In this study, we analyzed AF samples at the beginning of the second trimester and focused on IGFBP3 protein quantification and IGF-I/IGFBP3 polymorphisms analysis in three different groups: SGA, AGA, and LGA. We hypothesized that one of these biochemical/genetic markers could be predictive of abnormal fetal growth although an increase in IGFBP3 levels could lead both to an increase in IGF-I stability (stimulatory effect) and an increase in sequestration of the growth factor (inhibitory effect), depending on the context.

\section{Materials and methods}

\subsection{Subjects}

AF samples were obtained from women with singleton pregnancies admitted for amniocentesis at the Lausanne University Hospital in 2003-2004. Amniocentesis indications were maternal anxiety, maternal age $>35$ years, pathological T21 screening tests (predictive value $>1: 380$ ) or family history of chromosomal abnormality.

Inclusion criteria were amniocentesis at 14-18 weeks of gestation and delivery after 37 weeks. Exclusion criteria were maternal $\mathrm{HIV}^{+}, \mathrm{HBV}^{+}$, systemic disease or primo-infection (cytomegalovirus, toxoplasmosis, rubella, syphilis and varicella), and fetal malformation or chromosomal abnormality.

SGA was defined by ultrasonographic follow-up during the second/third trimester showing a biometry $<10$ th percentile and a newborn birth weight $<10$ th percentile [23], AGA by a newborn birth weight between 10th and 90th percentile and LGA by a newborn birth weight $>90$ th percentile. Gestational age was based exclusively on first trimester ultrasound ( $8-10$ weeks of gestation). 378 samples were obtained. Out of them, the first 123 AGA only were analyzed, plus all SGA (39 samples) and all LGA ( 34 samples), to obtain the 180 samples necessary for our analysis following our sample size calculation. Three SGA cases with uterine pathological Doppler were excluded, in order to have a homogeneous SGA population.

This protocol was approved by IRB of Biology/Medicine Faculty of Lausanne University. All patients were informed and asked for their consent before the study. All maternal/fetal data were prospectively recorded and assigned a number to ensure patient anonymity.

\subsection{Samples}

One milliliter AF was centrifuged $5 \mathrm{~min}$ at $2500 \mathrm{rpm}$. Supernatant was stored at $-80^{\circ} \mathrm{C}$ and cell pellet used for DNA extraction by adding $240 \mu \mathrm{NID}$ ( $50 \mathrm{mM} \mathrm{KCL}, 10 \mathrm{mM}$ Tris- $\mathrm{HCl}$ pH $8.3,2.5 \mathrm{mM}$ $\left.\mathrm{MgCl}_{2}, 1 \% \mathrm{Brij} 35\right)$ and $10 \mu \mathrm{l}$ proteinase $\mathrm{K}(5 \mathrm{mg} / \mathrm{ml})$. Sample was incubated $1 \mathrm{~h}$ at $56^{\circ} \mathrm{C}, 10 \mathrm{~min}$ at $95^{\circ} \mathrm{C}$, and stored at $-80^{\circ} \mathrm{C}$. Supernatant was used for protein quantification and pellet for polymorphism studies.

\subsection{IGFBP3 quantification}

IGFBP3 AF concentrations were measured by ELISA (Biosource Europe SA, Belgium). Detection limit was $10.5 \mathrm{ng} / \mathrm{ml}$, and there was no cross-reactivity for IGF-I, IGFBP1 and IGFBP2.

\subsection{IGF-I VNTR polymorphism}

Polymorphic region ( -841 in the promoter) was amplified by PCR with primers: 5'-GCTTCTATTGCTAGCCAGCTGGTGT-FAM-3' and $5^{\prime}$-GGGCAAACAATTTTCCTGT-3'. Reaction was carried out in $25 \mu \mathrm{l}: 10 \mu \mathrm{l}$ DNA, $2.5 \mu \mathrm{l} 10 \times$ PCR buffer, $0.5 \mu \mathrm{l} 10 \mathrm{mM}$ dNTPs, $0.15 \mu \mathrm{l}$ Taq DNA polymerase (Roche), $0.5 \mu \mathrm{l}$ each primer $(50 \mu \mathrm{M})$ and $1.5 \mu \mathrm{l}$ DMSO. Amplification was: 2 min at $94^{\circ} \mathrm{C}, 35$ cycles of $1 \mathrm{~min}$ at $94{ }^{\circ} \mathrm{C}, 30 \mathrm{~s}$ at $62^{\circ} \mathrm{C}$ and $45 \mathrm{~s}$ at $72{ }^{\circ} \mathrm{C}$, and $7 \mathrm{~min}$ at $72^{\circ} \mathrm{C}$.

Table 1

Maternal, newborn and amniotic fluid characteristics in SGA, AGA and LGA patient groups.

\begin{tabular}{|c|c|c|c|}
\hline & $\operatorname{SGA}(n=39)$ & $\operatorname{AGA}(n=123)$ & $\operatorname{l.GA}(n=34)$ \\
\hline \multicolumn{4}{|l|}{ Mother } \\
\hline Age (years) & $35.0 \pm 4.8(21-43)$ & $35.7 \pm 4.3(23-44)$ & $35.7 \pm 5.0(24-45)$ \\
\hline Gravidity & $2.0 \pm 0.9(1-4)^{\prime}$ & $2.6 \pm 1.5(1-8)$ & $2.8 \pm 1.9(1-10)$ \\
\hline Parity. & $0.6 \pm 0.8(0-3)^{\circ}$ & $1.0 \pm 0.9(0-4)$ & $1.4 \pm 1.1(0-5)^{\circ}$ \\
\hline $\mathrm{BMI}\left(\mathrm{kg} / \mathrm{m}^{2}\right)$ & $23.2 \pm 3.5$ & $23.5 \pm 3.8$ & $24.9 \pm 3.9$ \\
\hline Ethnic origin: catucasian (\%) & 87.2 & 86.8 & 88.2 \\
\hline Smoking (\%) & 5.3 & 5.0 & 2.9 \\
\hline PIH/GD (\%) & 10.5 & 8.4 & 2.9 \\
\hline \multicolumn{4}{|l|}{ Newborn } \\
\hline Bittl weight (BW) (g) & $2526 \pm 257^{\circ}$ & $3349 \pm 313$ & $4075 \pm 249^{\circ}$ \\
\hline Placenta weight (PW) (g) & $438 \pm 91^{\circ}$ & $607 \pm 116$ & $697 \pm 115^{\circ}$ \\
\hline PW/BW ratio & 0.17 & 0.18 & 0.17 \\
\hline $\mathrm{GA}$ at time of delivery (weeks) & $38.9 \pm 1.2$ & $39.3: 1.2$ & $39.0 \pm 1.2$ \\
\hline Method of delivery ratio ( $\%$ CS) & $43.6^{t}$ & 21.1 & 32.4 \\
\hline Gender (zy male) & $28.2^{t}$ & 52.0 & $79.4^{\dagger}$ \\
\hline \multicolumn{4}{|l|}{ Ammiotic fluid } \\
\hline $\mathrm{GA}$ at time of amniocentesis (weeks) & $16.5 \pm 0.8$ & $16.5 \pm 0.8$ & $16.5 \pm 0.7$ \\
\hline IGFBP3 $(\mathrm{ng} / \mathrm{ml})$ & $6359 \pm 384$ & 5384 上 219 & $5015 \pm 288$ \\
\hline . Independent Sample t-test & $P=0.030$ & & NS \\
\hline ANCOVA analysis" & $P=0,009$ & & NS \\
\hline
\end{tabular}

$\mathrm{PIH}=$ pregnancy-induced hypertension; $G D=$ gestational diabetes; $G A=$ gestational age; $C S=$ caesarean section; NS = not significant. Data are presented as mean \pm s.d. except for IGFBP3 values (mean \pm s.e.m.). Minima-maxima are indicated in brackets.

$P<0.05$ versus AGA by independent Sample. $t$-test.

$+P<0.05$ versus AGA by Mann-Whitney $U$-test.

†. $P<0.05$ versus AGA by Fisher's exact test.

a Covariates include gestational age at the time of aminiocentesis, maternal BMI, gravidity, parity, ethnic origin, age, smoking and PIH/GD status, and fetal gender. 
PCR product size was dẹtermined by Genescan analysis (Microsynth, Balgach, Switzerland). Product size correlated with $\mathrm{CA}$ repeat number, Ten samples were sequenced to check Genescan analysis accuracy.

\subsection{IGFBP3(A-202C) polymorphism}

Polymorphic region ( -202 in the promoter) was amplified by PCR with primers: $5^{\prime}$-CCGAGAGCGGAAGGGGTAAG-3' and $5^{\prime}-$ CCCGTGCTTCGCCCTGAGCA-3'. Reaction was carried out as above but amplification was: 2 min at $94{ }^{\circ} \mathrm{C}, 35$ cycles of $30 \mathrm{~s}$ at $94^{\circ} \mathrm{C}, 30 \mathrm{~s}$ at $65^{\circ} \mathrm{C}$ and $15 \mathrm{~s}$ at $72^{\circ} \mathrm{C}$, and $7 \mathrm{~min}$ at $72^{\circ} \mathrm{C}$. Avi Il restriction enzyme (Roche) was used for PCR digestion ( 1 h at $37^{\circ} \mathrm{C}$ ) and DNA fragments were analyzed on $2 \%$ agarose gels. Non-mutated allele yielded a 244 bp fragment, and mutated allele two fragments of 164 and $80 \mathrm{bp}$.

\subsection{Statistical analyses}

Results are expressed as mean \pm standard deviation (s.d.) for patient characteristics and mean \pm standard error of means (s.e.m.) for IGFBP3 concentrations. Student's $t$, Mann-Whitney $U$, KruskallWallis $H$, Fisher's exact or $\mathrm{Chi}^{2}$ tests were used for maternal/newborn characteristics (depending on the type of variable and of variance between groups). ANCOVA analysis was used for IGFBP3 concentrations, using gestational age at the time of amniocentesis, maternal BMI, gravidity, parity, ethnic origin, age, smoking and PIH/GD status and fetal gender as covariates. Binary logistic regression analysis was used to evaluate genotype results versus other parameters potentially influencing fetal growth. Receiver operating characteristic curve analysis was used to evaluate correlation between IGFBP3 concentration and fetal growth phenotype. All statistical analyses were performed using SPSS 14.0 software (SPSS Inc., Chicago, IL) and differences were significant when $P<0.05$.

\section{Results}

\subsection{Subjects}

A total of 196 patients were included in this study, which were 39 SGA, 123 AGA and 34 LGA. Maternal characteristics were comparable in all three groups, except gravidity and parity, which were lower in SGA and higher in LGA compared to AGA group $(P<0.05$ versus AGA group, except for gravidity in LGA group) (Table 1). For newborn characteristics, rate of caesarean section was significantly higher in SGA than in AGA group $(P=0.006)$, probably due to patient management in case of fetal growth restriction (Table 1). Birth weights were of course significantly different in the three groups, with mean values of $2526 \pm 257 \mathrm{~g}$ in SGA, $3349 \pm 313 \mathrm{~g}$ in AGA and $4075 \pm 249 \mathrm{~g}$ in LGA group $(P<0.001$ versus $A G A$ group in both cases). Placenta weights were also significantly higher in LGA $(697 \pm 115 \mathrm{~g})$ and lower in SGA $(438 \pm 91 \mathrm{~g})$ compared to AGA group $(607 \pm 116 \mathrm{~g})(P=0.002$ and $P<0.001$, respectively), while placenta to birth weight ratio was not significantly modified ( 0.17 in SGA and LGA, versus 0.18 in AGA group, NS in both cases). Finally, there was a 1.5 -fold higher percentage of males in LGA and a 1.8-fold lower percentage of males in SGA, compared to AGA group $(P=0.004$ and 0.010 , respectively).

\subsection{IGFBP3 concentration}

IGFBP3 AF concentrations were significantly higher in SGA than in AGA group $(6359 \pm 384$ versus $5384 \pm 219 \mathrm{ng} / \mathrm{ml}, P=0.030)$, while there was no statistical difference between AGA and LGA groups $(5384 \pm 219 \mathrm{ng} / \mathrm{ml}$ versus $5015 \pm 288 \mathrm{ng} / \mathrm{ml}$, respectively) (Fig. 1A, Table 1). However, IGFBP3 AF concentration also increased
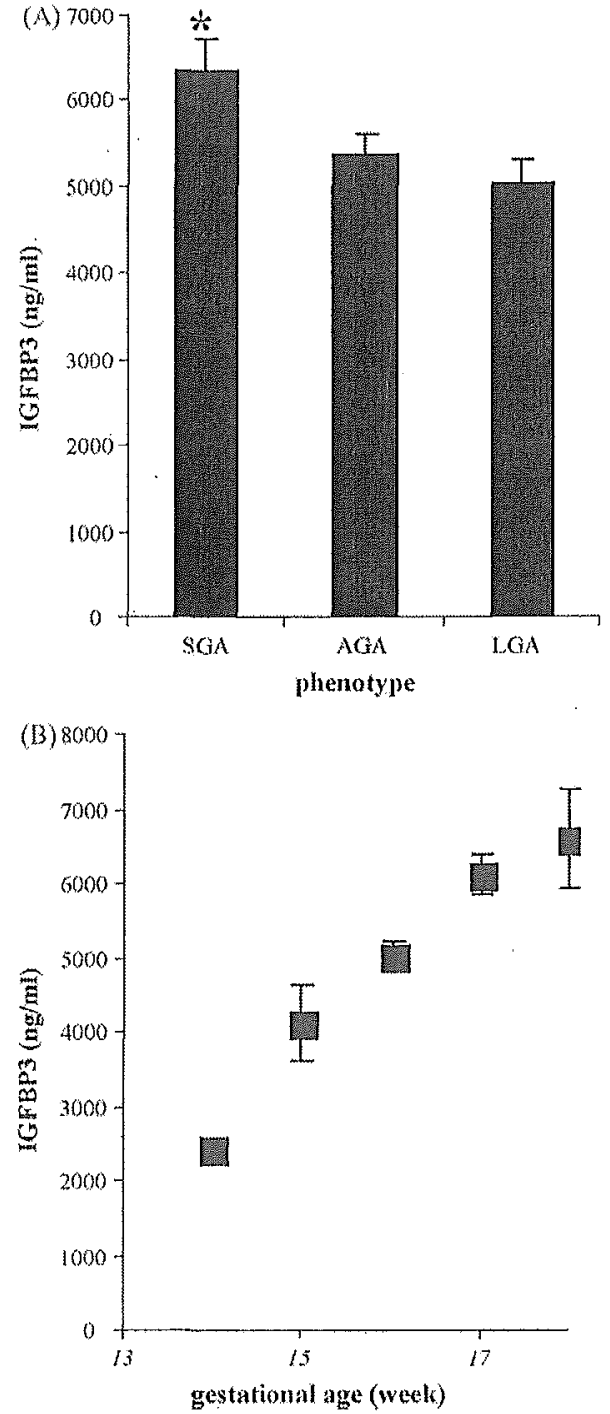

Fig. 1. (A) Amniotic fluid IGFBP3 concentrations are higher in SGA than in AGA group. (B) Amniotic fluid IGFBP3 concentrations proportionally increase with gestational age. Results are expressed as mean \pm s.e.m. AF IGFBP3 concentrations were measured by ELISA. Statistical analysis were done by independent Sample t-test and ANCOVA analysis and restults were considered significant when $P<0.05{ }^{*} P<0.05$ vs. AGA group.

with gestational age (Fig. 1B) and when gestational age and other factors such as maternal BMI, gravidity, parity, ethnic origin, age, smoking and PIH/GD status, and fetal gender were taken into account, the difference between SGA and AGA values was even more significant (ANCOVA analysis: $P=0.009$ ) (Table 1 ). A receiver operating characteristic curve analysis was performed on a subgroup of patients (16-17 weeks of gestation) to minimize the effect of gestational age but to not significantly affect the size of the sample. Area under the curve (AUC) indicated a fair predictive value of IGFBP3 AF concentrations for $S G A(A U C=0.7,95 \% \mathrm{Cl}=0.6-0.8, P=0.005)$, and the cut-off value giving the best sensitivity (70\%) and specificity (61\%) was $5445 \mathrm{ng} / \mathrm{ml}$ (data not shown).

\subsection{IGF-I VNTR polymorphism}

IGF-I VNTR allele distribution was wide, varying from 16 to 22 CA repeats, $19 \mathrm{CA}$ being the most common allele (Table 2). Allele distribution was not statistically modified in SGA, compared to 
Table 2

Amniotic fluid IGFBP3 concentration by genotype, and IGF-1/IGFBP3 polymorphisms results in SGA, AGA and LGA patient groups.

\begin{tabular}{|c|c|c|c|c|c|c|c|c|c|}
\hline & \multirow{2}{*}{\multicolumn{2}{|c|}{$\frac{A F \text { concentration }}{\text { IGFBP3 }}$}} & \multicolumn{7}{|c|}{ Phenotype groups } \\
\hline & & & \multicolumn{3}{|l|}{$\mathrm{SGA}$} & \multirow{2}{*}{$\begin{array}{l}\text { AGA } \\
n(\%)\end{array}$} & \multicolumn{3}{|l|}{ LGA } \\
\hline & $\mathrm{ng} / \mathrm{ml}$ & $p^{*}$ & $n(\%)$ & Odkls ratio $(95 \% \mathrm{Cl})$ & $p$ & & $11(\%)$ & Odds ratio $(95 \% \mathrm{Cl})$ & $P$ \\
\hline \multicolumn{10}{|l|}{ IGF-I VNTR } \\
\hline \multicolumn{10}{|l|}{ Cenotype } \\
\hline $19 \mathrm{CA} / 19 \mathrm{CA}$ & $5344 \pm 212$ & & $19(48.7)$ & 1.000 & & $55(44.7)$ & $16(47.1)$ & 1.000 & \\
\hline $19 \mathrm{CA} / 20 \mathrm{CA}$ & $5641 \pm 312$ & NS & $4(10.3)$ & $0.289(0.1-0.9)$ & 0.032 & $40(32.5)$ & $7(20.6)$ & $0.602(0.2-1.6)$ & NS \\
\hline $19 \mathrm{CA} / 21 \mathrm{CA}$ & $7080 \pm 939$ & 0.050 & $4(10.3)$ & $1.053(0.3-3.7)$ & NS & $11(8.9)$ & $3(8.8)$ & $0.938(0.2-3.8)$ & NS \\
\hline $18 \mathrm{CA} / 19 \mathrm{CA}$ & $4815 \pm 561$ & NS & $4(10.3)$ & $2.8 .95(0.7-12.7)$ & NS & $4(3.3)$ & $1(2.9)$ & $0.859(0.1-8.2)$ & NS \\
\hline Other & $5047 \pm 388$ & NS & $8(20.5)$ & $1.781(0.6-5.0)$ & NS & $13(10.6)$ & $7(20.6)$ & $1.841(0.6-5.4)$ & NS \\
\hline \multicolumn{10}{|l|}{ Allele } \\
\hline $16 \mathrm{CA}$ & & & $1(1.3)$ & NA & & $0(0.0)$ & $0(0.0)$ & $\mathrm{NA}$ & \\
\hline $17 C A$ & ' & & $0(0.0)$ & NA & & $4(1,6)$ & $0(0.0)$ & $\mathrm{NA}$ & \\
\hline $18 \mathrm{CA}$ & & & $6(7.7)$ & $3.288(1.0-10.6)$ & NS & $6(2.4)$ & $2(2.9)$ & $1.213(0.2-6.2)$ & NS \\
\hline $19 \mathrm{CA}$ & & & $52(6 G, 7)$ & 1.000 & & $171(69.5)$ & $47(69.1)$ & 1.000 & \\
\hline $20 C A$ & & & $11(14.1)$ & $0.754(0.4-1.6)$ & NS & $48(19.5)$ & $13(19.1)$ & $0.985(0.5-2.0)$ & NS \\
\hline $21 \mathrm{CA}$ & & & $7(9.0)$ & $1.771(0.7-4.7)$ & NS & $13 .(5.3)$ & $3(4.4)$ & $0.840(0.2-3.1)$ & NS \\
\hline $22 \mathrm{CA}$ & & & $1(1.3)$ & $0.822(0.1-7.5)$ & NS & $4(1.6)$ & $3(4.4)$ & $2.729(0.6-12.6)$ & NS \\
\hline \multicolumn{10}{|l|}{$I G F B P 3 S N P$} \\
\hline \multicolumn{10}{|l|}{ Genotype } \\
\hline $\mathrm{AA}$ & $5237 \pm 265$ & & $12(31.6)$ & 1.000 & & $32(26.0)$ & $7(21.2)$ & 1.000 & \\
\hline$A C$ & $5667 \pm 230$ & NS & $18(47.4)$ & $0.706(0.3-1.6)$ & NS & $68(55.3)$ & $21(63.6)$ & $1.412(0.5-3.7)$ & NS \\
\hline $\mathrm{CC}$ & $5523 \pm 168$ & NS & $8(21.1)$ & $0.928(0.3-2.6)$ & NS & $23(18.7)$ & $5(15.2)$ & $0.994(0.3-3.5)$ & NS \\
\hline \multicolumn{10}{|l|}{ Allele } \\
\hline$A$ & & & $42(55.3)$ & 1.000 & & $132(53.7)$ & $35(53.0)$ & 1.000 & \\
\hline C & & & $34(44.7)$ & $0.937(0.6-1.6)$ & NS & $114(46.3)$ & $31(47,0)$ & $1.026(0.6-1.8)$ & - NS \\
\hline
\end{tabular}

NA $=$ not applicable; NS = not significant; ${ }^{A}$ ANCOVA analysis with covariates including gestational age at the time of amniocentesis, maternal BMI, gravidity, parity, ethnic origin, age, smoking and $\mathrm{PIH} / \mathrm{GD}$ status, and fetal gender; $\mathrm{PIH}=$ pregnancy-induced hypertension; $G D=$ gestational diabetes; GA $=$ gestational age; NS $=$ not significant.

AGA group, but a statistically significant difference was observed between SGA and AGA groups at the genotype level $(P=0.029)$. 19CA/20CA genotype was three-fold less frequent in SGA than in AGA group, which corresponded to a decreased risk of SGA occurrence compared to the most common 19CA/19CA genotype: $\mathrm{OR}=0.289,95 \% \mathrm{CI}=0.1-0: 9, P=0.032$. No statistical difference was observed in allele or genotype distribution between LGA and AGA groups.

Global analysis of the different factors potentially responsible for SGA phenotype indicated that IGF-I 19CA/20CA genotype was a statistically significant component of the equation, as was primiparity ( $P=0.045$ and 0.034 , respectively) (Table 3 ).

Table 3

Logistic regression analysis of the contribution of suspected/known risk factors to the final SGA phenotype.

\begin{tabular}{|c|c|c|c|}
\hline & \multicolumn{3}{|l|}{ Phenotype (SCA) } \\
\hline & $\operatorname{Exp}(B)=$ Odds latio & $95 \% \mathrm{Cl}$ & $P$ \\
\hline \multicolumn{4}{|l|}{ Mother } \\
\hline Ethnic origìn & 0.969 & $0.3-3.1$ & NS \\
\hline [गII/GD & 1.293 & $0.3-5.6$ & NS \\
\hline Smoking & 1.255 & $0.2-9.6$ & NS \\
\hline Primiparity & 2.362 & $1.1-5.2$ & 0.034 \\
\hline Age & 0.954 & $0.9-1.0$ & NS \\
\hline BMI $\left(\mathrm{kg} / \mathrm{m}^{2}\right)$ & 0.992 & $0.9-1.1$ & NS \\
\hline \multicolumn{4}{|l|}{ Newilorn } \\
\hline IGF-I polymorphism: & & & NS \\
\hline $19 \mathrm{CA} / 20 \mathrm{CA}$ & 0.290 & $0.1-1.0$ & 0.045 \\
\hline $19 \mathrm{CA} / 21 \mathrm{CA}$ & 0.794 & $0.2-3.0$ & NS \\
\hline $18 \mathrm{CA} / 19 \mathrm{CA}$ & 2.164 & $0.4-11.6$ & NS \\
\hline other & 1.495 & $0.5-4.4$ & NS \\
\hline Constant & 1.547 & & NS \\
\hline
\end{tabular}

IGFBP3 AF concentrations were statistically higher in IGF-I VNTR genotype 19CA/21CA, compared to 19CA homozygotes (Table 2).

\subsection{IGFBP3(A-202C) polymorphism}

In AGA group, $A$ and $C$ alleles were present with almost the same frequency (53.7 and 46.3\%, respectively) (Table 2). AC was the predominant genotype (55.3\% of the population) and no significant differences in allele or genotype distribution were observed between SGA or LGA, and AGA groups.

No difference in IGFBP3 AF concentrations was observed between IGFBP3 SNP genotypes (Table 2).

\section{Comment}

Most of the studies looking at the fetal somatotropic axis have studied cord blood at delivery. Here, we focused on IGFBP3 concentrations at the beginning of the second trimester and studied fetal genetic profiles of IGF-I and IGFBP3 gene polymorphisms in search of predictive markers of abnormal fetal growth.

Maternal and fetal characteristics showed several features already reported, like a gravidity/parity higher in LGA and lower in SGA and a newborn male gender prevalence higher in LGA $[24,25]$, or even a placenta weight and placenta to newborn birth weight ratio smaller in SGA (significant for placenta weight only in our sample collective) [26].

AF IGFBP3 concentrations in SGA group were higher than in AGA or even in LGA groups, no matter what the gestational age. Spearman's correlation analysis indicated a highly significant relationship between IGFBP3 concentrations and newborn percentile: <5th (severe SGA) $(6403 \pm 559 \mathrm{ng} / \mathrm{ml})$, 5th-10th (light $\mathrm{SGA}$ ) (6313 $\pm 539 \mathrm{ng} / \mathrm{ml}), 10$ th-50th ("small" AGA) (5654 $\pm 294 \mathrm{ng}$ / $\mathrm{ml})$, 50th-90th ("large" AGA) $(5151 \pm 319 \mathrm{ng} / \mathrm{ml})$, >90th percentile (LGA) $(5015 \pm 288 \mathrm{ng} / \mathrm{ml})(P=0.001)$ (data not shown). On the 
contrary, Tisi et al. reported a positive correlation between AF IGFBP3 concentrations and newborn birth weight in macrosomes [15]. This discrepancy could be due to the degree of ethnic heterogeneity of their population (69\% Caucasian versus $87 \%$ in ours). But it could also be due to the fact that the positive correlation reported was only found in LGA, whereas their mean IGFBP3 values did not differ between SGA, AGA and LGA [15].

The overall allele distribution of IGF-I VNTR found in our study was similar to previous reports (70\% 19CA, 20\% 20CA, 5\% 21CA and $2 \% 18 \mathrm{CA}$ repeats) $[18,19]$, and it was in Hardy-Weinberg equilibrium. Only one genotype, 19CA/20CA, was associated to a modified (reduced) risk of SGA occurrence. Vaessen et al. had previously described an association between the absence of 19CA in the fetal genome and a reduction in birth weight compared to 19CA homozygotes [27]. We also found a threefold increase in genotypes without 19CA in SGA compared to AGA group (15.4\% versus $5.7 \%$ ), but the risk of SGA occurrence linked with this absence was not statistically modified compared to the presence of one $19 \mathrm{CA}(\mathrm{OR}=3.731,95 \% \mathrm{Cl}=1.1-12.8, P=0.066)$ or compared to 19CA homozygotes ( $\mathrm{OR}=2.481,95 \% \mathrm{CI}=0.7-8.3, P=0.183$ ). This difference could be due to our sample size, as only $6-7$ individuals were devoid of 19CA allele in SGA and AGA groups, but it could also be due to the fact that the reduction in birth weight reported did not take into account the birth weight percentile [27].

Genotype distribution of IGFBP3 SNP was similar to previous studies that showed a marked predominance of $A C$ genotype (54\%) [21,22], and it followed the Hardy-Weinberg law. AA genotype was shown to correlate with higher IGFBP3 circulating concentrations than $\mathrm{AC}$ and finally $\mathrm{CC}$ genotype in adults, although differences were low $[21,22]$. In our study, no association between IGFBP3 genotype and AF concentration was observed, even when the gestational age at the time of amniocentesis and the other maternal/fetal characteristics were controlled for (ANCOVA analysis: $P=0.337$ ). This could be due to the fact that factors regulating IGFBP3 gene expression during intrauterine life are different from those expressed at adulthood, or to the fact that $\mathrm{AF}$ concentrations are not proportional to circulating concentrations.

Morimoto et al. previously reported a cross-association between the absence of 19CA allele in IGF-I VNTR and higher IGFBP3 plasma concentrations [28] that we did not find in our study, no matter what the gestational age at the time of amniocentesis or the other maternal/fetal parameters used as covariates (ANCOVA analysis: $P=0.882$ ). However, in Morimoto et al. study, differences between 19CA homozygotes and the other genotypes were only of 5\% [28], and again, AF concentrations might simply not reflect circulating concentrations.

Mouse animal studies have shown that ubiquitous transgenic expression of IGFBP3 resulted in higher IGFBP3 and IGF-I circulating concentrations and a modest reduction in size of the transgenic pups (10\%) which persisted in early postnatal life [29]. On the other hand, IGFBP3 single KO showed no growth phenotype, but IGFBP3-5 triple KO exhibited the prenatal growth defect observed in IGFBP4 single KO, plus' a postnatal growth defect significant from day 20 and thereafter. This was associated with a decrease in IGF-I circulating concentrations and bioactivity [30]. It is clear that the presence of multiple members in the IGFBPs family allows compensation mechanisms between members. Moreover, IGFBPs have both inhibitory and stimulatory effects on IGF-I action, depending on the situation. In our study, we found that higher IGFBP3 AF concentrations were associated with lower birth weight percentile, coherent with the transgenic animal profile and with the fact that AF concentrations are proportional to circulating concentrations.

In summary, we have shown that IGFBP3 AF concentration at 14-18 weeks of pregnancy negatively correlated with newborn percentile. We also have shown that a particular IGF-I VNTR genotype, 19CA/20CA, was associated with a reduced risk of SGA occurrence to the same extent that primiparity was associated with an increased risk of SGA occurrence. These results taken together could help predict abnormal fetal growth in early pregnancy.

\section{Disclosure statement}

The authors have nothing to disclose.

\section{Acknowledgment}

We thank Fabien Murisier for comments on the manuscript.

\section{References}

[1] Rosenfeld RG. Insulin-like growth factors and the basis of growth. N Engl J Med 2003:349:2184-6.

[2] Monzavi R Cohen $\bar{Y}$. IGFs and IGFBPs: role in health and disease. Best Pract Res Clin Endocrinol Metab 2002;16:433-47.

[3] Holt RI. Fetal programming of the growth hormone-insulin-like growth factor axis. Trends Endocrinol Metab 2002;13:392-7.

[4] Verhaeghe J, Pintiaux A, Van Herck E, et al. IGF-I, IGF-binding protein-1, and leptin during a glucose challenge test in pregnant women: relation with maternal body weight, glucose tolerance, and birth weight. J Clin Endocrinol Metab 2002;87:2875-82.

[5] Dupont J, Holzenberger' $M$. Biology of insulin-like growth factors in development. Birth Defects Res C Embryo Today 2003;69:257-71.

[6] Baker J, Liu JP, Robertson E], Efstratiadis A. Role of insulin-like growth factors in embryonic and postnatal growth. Cell 1993;75:73i-82.

[7] DeChiara TM, Robertson E], Efstratiadis A. Parental imprinting of the mouse insulin-like growth factor II gene. Cell 1991;64:849-59.

(8) DeChiara TM, Efstratiadis A, Robertson EJ. A growth-deficiency phenotype in heterozygous mice carrying an insulin-like growth factor II gene disrupted by targeting. Nature 1990;345:78-80.

[9] Ranjaram S, Baylink DJ, Mohan S. Instlin-like growth factor-binding proteins in serum and other biological fluids: regulation and functions. Endocr Rev 1997; 18:801-31.

[10] Liu JP, Baker J, Perkins AS, Robertson EJ, Efstratiadis A. Mice carrying null mutations of the genes encoding insulin-like growth factor 1 (Igf-1) and type 1 IGF receptor (Igf1r). Cell 1993;75:59-72.

[11] Wang J, Zhou J, Powell-Braxton L, Bondy C. Effects of Igf1 gene deletion on postnatal growth patterns. Endocrinology 1999;140:3391-4.

[12] Domene HM, Bengolea SV, Jasper HG, Boisclair YR. Acid-labile subunit deficiency: phenotypic similarities and differences between human and mouse. I Endocrinol Invest 2005:28:43-6.

[13] Verhaeghe J, Coopmans W, van Herck E, van Schoubroeck D, Deprest JA, Witters L. IGF-I, IGF-II, IGF binding protein 1, and C-peptide in second trimester amniotic fluid are dependent on gestational age but do not predict weight at birth. Pediatr Res 1999;46:101-8.

[14] Roig MD, Sabria J, Valls C, et al. The use of biochemical markers in prenatal diagnosis of intrauterine growth retardation: insulin-like growth factor I, leptin, and alpha-fetoprotein. Eur J Obstet Gynecol Reprod Biol 2005;120: $27-32$.

[15] Tisi DK, Liu XJ, Wykes LJ, Skinner CD, Koski KG, Insulin-like growth factor II and binding proteins 1 and 3 from second trimester human amniotic fluid are associated with infant birth weight. J Nutr 2005;135:1667-72

[16] Jensen RB, Chellakooty M, Vielwerth S, et al. Intrauterine growth retardation and consequences for endocrine and cardiovascular diseases in adult life: does insulin-like growth factor-I play a role? Horm Res 2003;60(Suppl'3): $136-48$.

[17] Rosen C], Kurland ES, Vereault D, et al. Association between serum insulin growth factor-I (IGF-I) and a simple sequence repeat in IGF-I gene: implications for genetic studies of bone mineral density. J Clin Endocrinol Metab 1998;83:2286-90.

[18] Vaessen N, Heutink P, Janssen JA, Witteman JC, Testers L, Hofman A. A polymorphism in the gene for IGF-I: functional properties and risk for type 2 diabetes and myocardial infarction. Diabetes 2001;50:637-42.

[19] Frayling TM, Hattersley AT, McCarthy A, et al. A putative functional polymorphism in the IGF-I gene: association studies with type 2 diabetes, adult height, glucose tolerance, and fetal growth in U.K. populations. Diabetes $2002 ; 51: 2313-6$.

[20] Johnston LB, Dahlgren J, Leger], et al. Association between insulin-like growth factor I (IGF-I) polymorphisms, circulating IGF-1, and pre- and postnatal growth in two European small for gestational age populations. J Clin Endocrinol Metab 2003;88:4805-10.

[21] Jernstrom H, Deal C, Wilkin F, et al. Genetic and nongenetic factors associated with variation of plasma levels of insulin-like growth factor-I and insulin-like growth factor-binding protein-3 in healthy premenopausal women. Cancer Epidemiol Biomarkers Prev 2001;10:377-84. 
[22] Deal C, Ma J, Wilkin F, et al. Novel promoter polymorphism in insulin-like growth factor-binding protein-3: correlation with serum levels and interaction with known regulators. I Clin Endocrinol Metab 2001:86:1274-80.

[23] Hohlfeld P, Marty F, De Grandi P, Tissot J-D, Bossart H, Gerber S. Obstétrique, Le livre de l'interne. 3rd ed. Paris (F): Flammarion Médecine-Sciences, 2004.

[24] Adesina OA, Olayemi O. Fetal macrosomia at the University College Hospital, lbadan: a 3-year review. J Obstet Gynaecol 2003;23:30-3.

[25] Stotland NE, Caughey AB, Breed EM, Escoba G]. Risk factors and obstetric complications associated with macrosomia. Int J Gynecol Obstet 2004;87: $220-6$.

[26] Heinonen S, Taipale P, Saarikoski S. Weights of placentae from small-forgestational age infants revisited. Placenta 2001;22:399-404.
[27] Vaessen $N$, Janssen JA, Heutink $P$, et al. Association between genetic variation in the gene for insulin-like growth factor-I and low birthweight. Lancet $2002 ; 359: 1036-7$.

[28] Morimoto LM, Newcomb PA, White E, Bigler J Potter JD. Variation in plasma insulin-like growth factor-1 and insulin-like growth factor binding protein-3: genetic factors, Cancer Epidemiol Biomarkers. Prev 2005:14:1394-401.

[29] Modric T, Silha JV, Shi Z, et al. Phenotypic manifestations of insulin-like growth factor-binding protein-3 overexpression in transgenic mice. Endocrinology 2001:142:1958-67.

(30) Ning Y, Schuller AG, Bradshaw S, et al. Diminished growth and enhanced glucose metabolism in triple knockout mice containing mutations of insulin-like growth factor binding protein-3, -4 , and -5 . Mol Endocrinol 2006;20:2173-86. 